Document downloaded from:

http://hdl.handle.net/10251/156507

This paper must be cited as:

Payri, R.; Hardy, G.; Gimeno, J.; Bautista-Rodríguez, A. (2019). Analysis of counterbore effect in five diesel common rail injectors. Experimental Thermal and Fluid Science. 107:6978. https://doi.org/10.1016/j.expthermflusci.2019.05.008

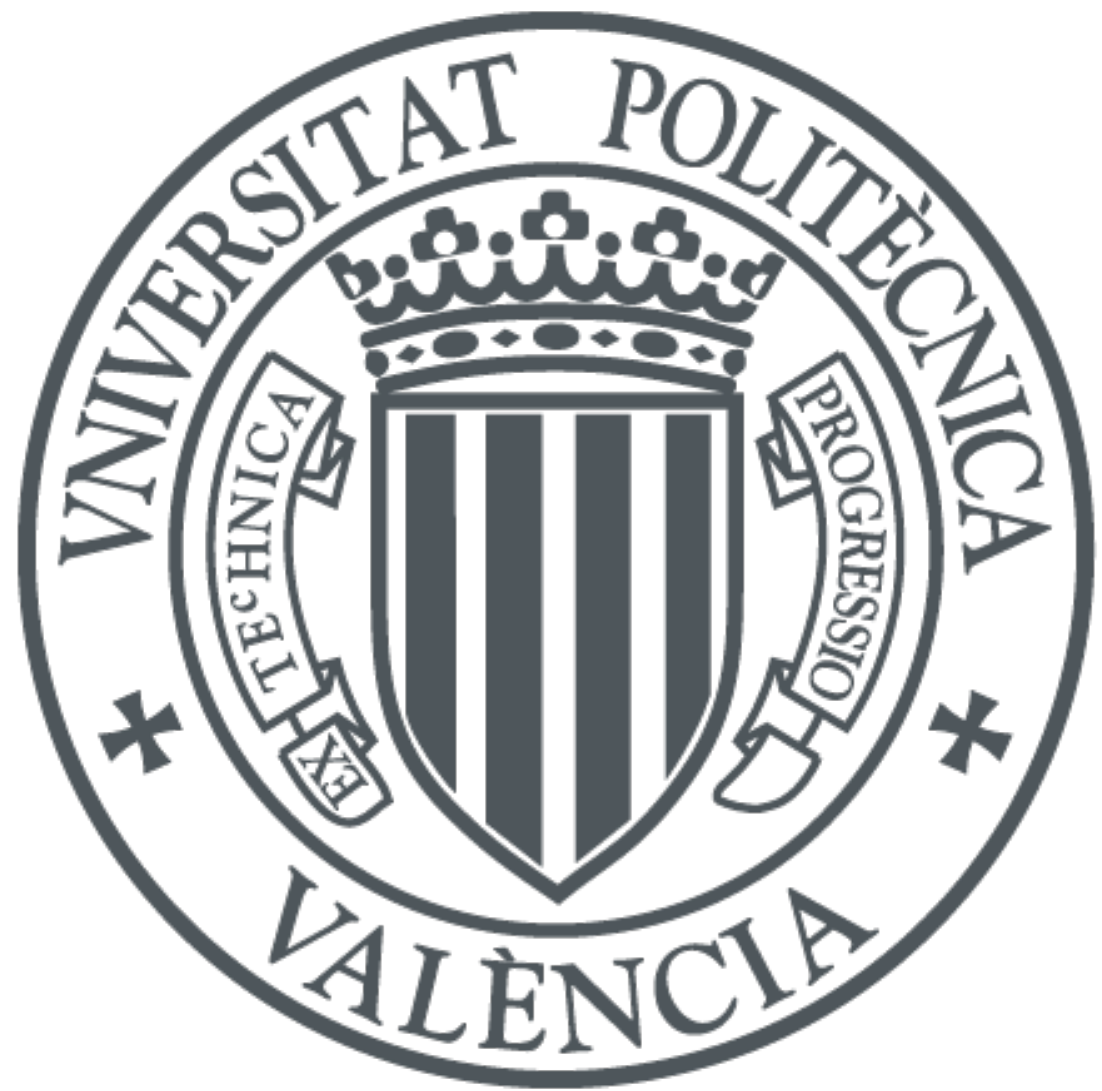

The final publication is available at

https://doi.org/10.1016/j.expthermflusci.2019.05.008

Copyright Elsevier

Additional Information 
Payri, R., Hardy, G., Gimeno, J., Bautista, A. (2019). Analysis of counterbore effect in five diesel common rail injectors. Experimental Thermal and Fluid Science, 107(February), 6978. https://doi.org/10.1016/j.expthermflusci.2019.05.008

\title{
Analysis of counterbore effect in five Diesel common rail injectors
}

\author{
Raul Payri ${ }^{\mathrm{a}, *}$, Gilles Hardy ${ }^{\mathrm{b}}$, Jaime Gimeno ${ }^{\mathrm{a}}$, Abian Bautista ${ }^{\mathrm{a}}$ \\ ${ }^{a}$ CMT - Motores Térmicos, Universitat Politècnica de València, Edificio 6D, 46022, \\ Valencia, Spain. \\ ${ }^{b}$ FPT Motorenforschung AG Schlossgasse 2, Postfach, CH-9320 Arbon, Switzerland
}

\begin{abstract}
The present work assesses how the nozzle geometry, particularly the counterbore which is used in gasoline direct injection, could improve the fuel mixture when injecting in diesel engines, and ultimately, increase the thermal efficiency of the engine. Five different injector's nozzles are tested using a parametric variation over counterbore dimensions. For this purpose, measurements of the rate of injection, spray momentum and non-evaporative visualization are performed. Comparison of the nozzles performance is assessed by the rate of injection and momentum, nozzle coefficients in the hydraulic part, and in terms of spray penetration and spray angle in the visualization part which describe the macroscopic characteristics of spray development. Minimal variation was found observing at the hydraulic characterization of the injectors. On the other hand, a more notable difference was found in the visualization experiments, in which the modified nozzles presented greater spray angles and smaller penetration than the original one without counterbore. This work provides an insight into the potential effects of using the popular counterbore -used in gasoline direct injection (GDI)- in a diesel injector.
\end{abstract}

Keywords: Diesel, Counterbore, Nozzle geometry, Rate of injection, Spray momentum, MIE scattering.

*Corresponding author. E-mail address: rpayri@mot.upv.es 
Payri, R., Hardy, G., Gimeno, J., Bautista, A. (2019). Analysis of counterbore effect in five

diesel common rail injectors. Experimental Thermal and Fluid Science, 107(February), 6978.

https://doi.org/10.1016/j.expthermflusci.2019.05.008

\section{Introduction}

Energy consumption and emissions production from internal combustion engines remain the two most important critical factors in the design and development of engines [1]. Diesel engines are still a fundamental part of the automotive sector [2], but are considered an environmental concern due to pollutants emissions. The increasing regulations from governments have motivated efforts to be put in the development of more efficient engines. The efficiency of the diesel engines is highly dependent on the quality of the combustion, in which the component that plays the major role is the injector. It is the main component of the fuel injection system which delivers the fuel spray in the engine [3]. By improving its performance, it could achieve better use of the fuel. Over the last decades, the researchers have studied fuel sprays meticulously to obtain knowledge and understanding of these complex phenomena. Also, many research studies have been done to obtain reliable data that allows validating numerical simulations [4.

The injectors can be evaluated in terms of hydraulic characteristics -which states the performance of the internal injector flow- and in terms of macroscopic spray characteristics, in which liquid/vapor penetration and distribution are analyzed [5] 8. The macroscopic spray characteristics are the ones that significantly affects the combustion and emissions processes [9 11]. By optimizing these characteristics, the tailpipe emissions: mainly oxides of nitrogen (NOx) and particulate matter (PM), can be minimized.

The modifications performed in the nozzle geometry of diesel injectors have been traditionally addressed to gain deeper knowledge about the cavitation of the inner flow when injecting at high pressures, where the conicity of the orifice plays a major role 12 19. Additionally, many studies have analysed the effect of nozzle geometry on the internal and external flow parameters by comparing the influence of the conical factor of the orifices [20 22], and also elliptical shape 23 25]. Other works, however, have addressed the performance of two nozzle geometries with different fuels $[5,26,27$. Moreover, some studies have 
Payri, R., Hardy, G., Gimeno, J., Bautista, A. (2019). Analysis of counterbore effect in five diesel common rail injectors. Experimental Thermal and Fluid Science, 107(February), 6978. https://doi.org/10.1016/j.expthermflusci.2019.05.008

investigated combustion performance [11, 27, 28, in which [11] did a study comparing 6 different geometries. All these works have in common that the geometry changes of the orifices have been done on the inner side or the conicity factor. Nonetheless, there are not studies for diesel injectors that compares the performances of nozzles with counterbore, which is a step-like shape modification in the outside part of the orifice. This kind of nozzles have only been study for gasoline direct injectors [29 34] whose results reported that although the inner hole has more significant influence on the spray characteristics than the counterbore, the latest can influence the spray angle due to the air entrained into the counterbore cavity and recirculation flow inside it. It is known that this stepped geometry could diminish its performance due to the formation of deposits over long-term usage [35]. This study aims to be a contribution to the current understanding of the effects of nozzle geometry over the macroscopic spray development for diesel injectors, which with the use of the counterbore geometry it potentially could achieve more air incorporation in the spray thus better fuel-air mixture for more efficient combustion. The experiments were performed for 5 parametric variations over counterbore nozzles geometries using conventional diesel fuel. The campaign covered a complete hydraulic characterization through instantaneous injection rate and momentum flux measurements, in addition to high-speed visualization of the isothermal liquid spray.

\section{Experimental tools and methodology}

This sections presents the experimental equipment and data processing methodology.

\subsection{Injectors}

Five diesel injectors with modifications made on the orifices in some of them were studied. The nozzle has 8 orifices equally axially distributed. The original injector has a orifice lenght and diameter of $0.725 \mathrm{~mm}$ and $0.137 \mathrm{~mm}$ respectively, resulting in an L/D relation of 5.2. Also, the orifices have a K-factor 
Payri, R., Hardy, G., Gimeno, J., Bautista, A. (2019). Analysis of counterbore effect in five diesel common rail injectors. Experimental Thermal and Fluid Science, 107(February), 6978. https://doi.org/10.1016/j.expthermflusci.2019.05.008

\begin{tabular}{|llll|}
\hline \multicolumn{2}{|c|}{ Nomenclature } & & \\
$\Delta P$ & Difference between injection & $P_{b a c k}$ & Back pressure \\
& and back pressure & $P_{r}$ & Rail pressure \\
$\dot{M}_{f}$ & Stabilized rate of momentum & CFD & Computational Fluid Dynam- \\
$\dot{m}_{f}$ & Stabilized rate of injection & & ics \\
$\rho_{f}$ & Density of the fuel & ET & Energizing time \\
$A_{0}$ & Outlet area of the injector & GDi & Gasoline direct injection \\
$C_{d}$ & Discharge coefficient & ROI & Rate of injection \\
$D_{e f}$ & Effective diameter & ROM & Rate of momentum \\
$D_{i}$ & Inlet diameter & STP & Standard Temperature and \\
$D_{o}$ & Outlet diameter & & Pressure \\
& & & \\
\hline
\end{tabular}

of 1.5, defined by equation 1 and shown in Figure 1 . Where $D_{o}$ is the outlet diameter, and $D_{i}$ is the inlet diameter. In this case, the spray holes have a positive conical shape factor, which exhibits an orifice with decreasing diameter toward the nozzle exit. A k-factor of zero indicates a cylindrical orifice since the diameters are equal. One of the five injectors is conserved with the original geometry. However, the other four are modified to study the effect of the counterbore. The modifications are made through drilling a counterbore which changes the depth and the diameter of the recess, as shown in Figure 2. The variations over the geometric parameters were done based on $[29 \sqrt[32]{32}$ geometries and performing variations trying to fix depth of the counterbore to see the effect of the diameter and vice versa. The characteristics of the injectors are presented in Table1. The relation L/D of the orifice is greater than 3 for all the injectors.

$$
k_{\text {factor }}=\frac{D_{i}-D_{o}}{10[\mu m]}
$$

\subsection{Test conditions and injection systems}

A whole common rail injection system was employed to generate high pressure in the test rig used in this study, similarly to the one used in [31, 36]. 
Payri, R., Hardy, G., Gimeno, J., Bautista, A. (2019). Analysis of counterbore effect in five diesel common rail injectors. Experimental Thermal and Fluid Science, 107(February), 6978. https://doi.org/10.1016/j.expthermflusci.2019.05.008

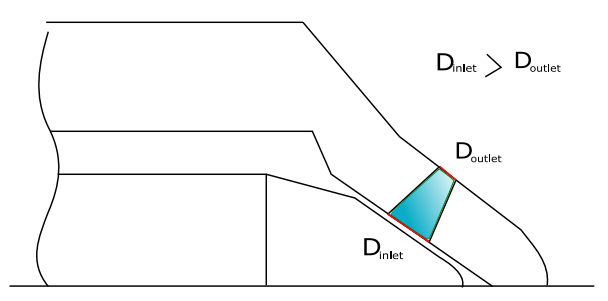

Figure 1: Sketch of a conic orifice.

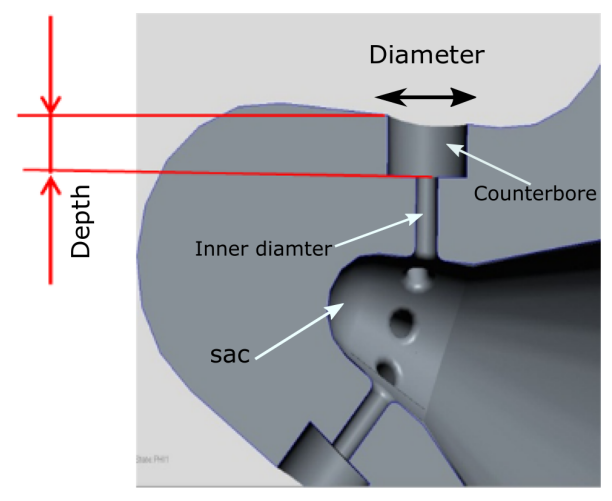

Figure 2: Draw of a nozzle with counterbore.

Table 1: Injectors properties

\begin{tabular}{|l|l|l|l|l|l|}
\hline & L/D & L/D counterbore & $\begin{array}{l}\text { Fraction of depth } \\
\text { of counterbore from } \\
\text { original length }\end{array}$ & $\begin{array}{l}\text { Times the diameter } \\
\text { of the original }\end{array}$ & Alias \\
\hline Injector 1. original & 5.2 & 0.0 & 0 & 1 & Original \\
\hline Injector $\mathbf{2}$ & 2.9 & 0.6 & 0.4 & 3.5 & L0.4D3.5 \\
\hline Injector 3 & 3.7 & 0.4 & 0.3 & 3.5 & L $0.3 \mathrm{D} 3.5$ \\
\hline Injector $\mathbf{4}$ & 4.4 & 0.2 & 0.15 & 3.5 & L0.15D3.5 \\
\hline Injector $\mathbf{5}$ & 3.1 & 1.1 & 0.4 & 2 & L0.4D2 \\
\hline
\end{tabular}

The arrangement is composed of the Bosch CRI2-20 injector, a common rail, thermo-regulator, a trigger generator which drives the signal to the Solenoid injector, and a high-pressure pump. The fuel tank is connected to a high-pressure pump which pressurizes the fuel and sends it to a diesel common rail. The common rail is instrumented with a kistler sensor to precisely measure the pressure and a PDI actuator to control it. The thermo-regulator permitted to set an injector holder temperature of $70^{\circ} \mathrm{C}$ for all experimental test conditions using glycol as cooling fluid. The selection of the temperature is based in engine-like temperatures similar to those used in Engine Combustion network guidelines and capabilities of the test equipment. The back pressure was set introducing nitrogen gas in the cavity of the test rig with, and it was varied from 20 to 120 bar. The duration of the energizing time (ET) was varied between 0.8 
Payri, R., Hardy, G., Gimeno, J., Bautista, A. (2019). Analysis of counterbore effect in five diesel common rail injectors. Experimental Thermal and Fluid Science, 107(February), 6978. https://doi.org/10.1016/j.expthermflusci.2019.05.008

Table 2: Test matrix for Measurements of Spray G injector.

\begin{tabular}{|l|l|l|}
\hline Name & Tested values & units \\
\hline Rail pressure & $400 / 800 / 1200 / 1600 / 2000$ & bar \\
\hline Back pressure & $20 / 45 / 80 / 120$ & bar \\
\hline Energizing time & $800 / 1500$ & $\mu \mathrm{s}$ \\
\hline Cycles for test condition & 50 & - \\
\hline
\end{tabular}

and $1.5 \mathrm{~ms}$. The experiments were performed systematically, changing the ET, Injection pressure and back pressure. The measurements were performed once enough time passed at each condition so the values were stabilized. The executed experimental matrix is summarized in Table 2, where there are captured the operative conditions range of the injectors.

\subsection{Rate of injection test rig}

The ROI test rig allows for measuring the ejected mass. It is a long-tubed type of commercial equipment. The sensor in the device can measure the timeresolved injection event. The measuring principle used is the Bosch method, which consists in injecting into a fuel-filled measuring tube. The back pressure is achieved with a cavity filled with nitrogen, which mitigates the pressure oscillations. Figure 4 depicts a diagram with the parts described. The fuel ejection creates a pressure increase inside the tube, which is proportional to the rise in fuel mass. The form of this signal links to the rate of injection.

It is collected 50 samples for each test condition using a high-speed acquisition system, varying: back pressure, injection pressure, and energizing time (ET). Then, the raw data is averaged and later corrected to account for the signal cumulative phenomenon [37. The resulting curve is integrated to obtain the total mass per injection. Finally, the amount injected is compared to the mass increase measured by a high precision scale located downstream. From the mass conservation consideration, both quantities should be equal, so the ROI curve is corrected to target the measurement of the scale. The standard 
Payri, R., Hardy, G., Gimeno, J., Bautista, A. (2019). Analysis of counterbore effect in five diesel common rail injectors. Experimental Thermal and Fluid Science, 107(February), 6978. https://doi.org/10.1016/j.expthermflusci.2019.05.008

deviation was below $3 \%$ for the case of $P_{r}=400$ bar and $1 \%$ for the rest of rail pressures. The measurement error on this device is typically around $0.5 \%$ after proper calibration, being more reliable for longer injections. Figure 3 illustrate a sketch describing the injection rate set up.

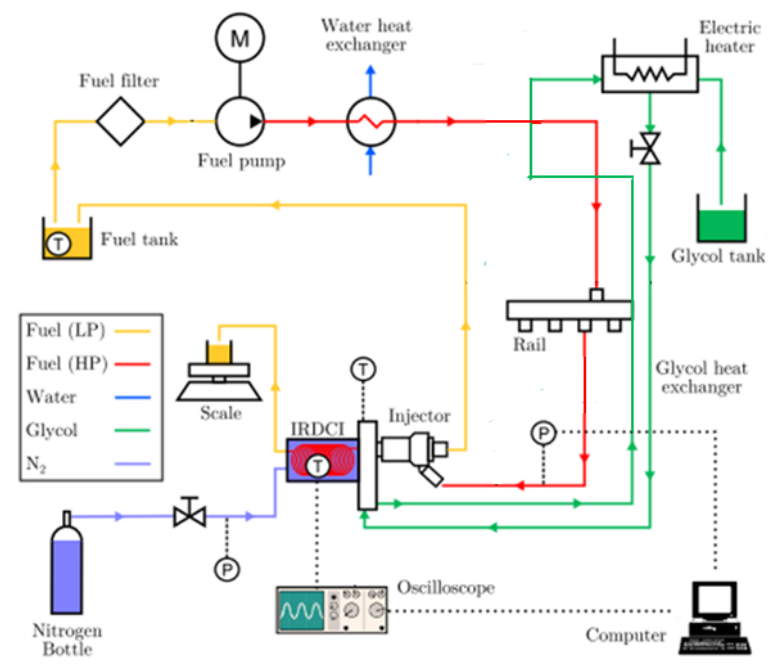

Figure 3: Sketch of the injection system.

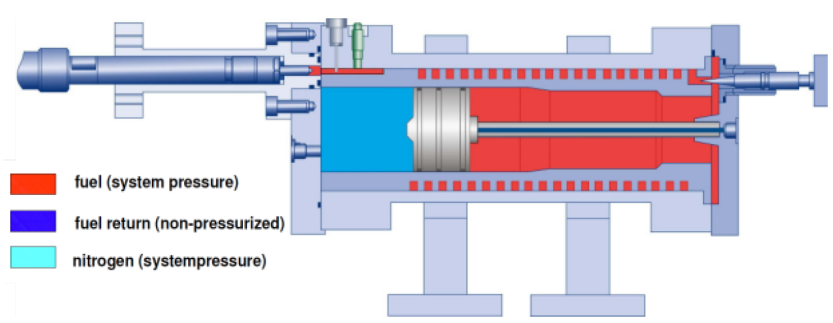

Figure 4: Diagram of the ROI parts [38.

\subsection{Rate of momentum test rig}

The rate of momentum test rig consists of a constant volume chamber with a piezoelectric pressure sensor calibrated to measure the momentum flux directly. It can be pressurized with nitrogen up to 100 bar. The complete description of 
Payri, R., Hardy, G., Gimeno, J., Bautista, A. (2019). Analysis of counterbore effect in five diesel common rail injectors. Experimental Thermal and Fluid Science, 107(February), 6978. https://doi.org/10.1016/j.expthermflusci.2019.05.008

the test rig can be found in [39]. It has a continuous fuel evacuation system, and the fuel pump and the thermoregulator are the same used in the injection rate test rig. It is capable of characterizing multi-hole nozzle, where hole to hole variations are evaluated. The assumption for spray momentum measurement are:

- Uniform chamber pressure.

- Incoming air velocity perpendicular to axis.

With these assumptions, the momentum flux can be independent on chamber pressure or distance from the origin because momentum is conserved in the axial direction. The sensor is placed at an angle to the nozzle, so the fuel spray hits the sensor target perpendicularly, and also only one single spray plume is capture at a time. The test matrix for this test was the same as the Rate of injection. Nevertheless, it was not measured the back pressure of 120 bar since it is not possible for the test rig.

The data acquisition procedure is the same as the rate of injection capturing 50 samples for each test point. The cumulative phenomenon was corrected. However, there was not performed a comparison with a scale downstream. The sensor provides a direct measure of the momentum flux. The measurement error for spray momentum was under $1 \%$ for the points acquired.

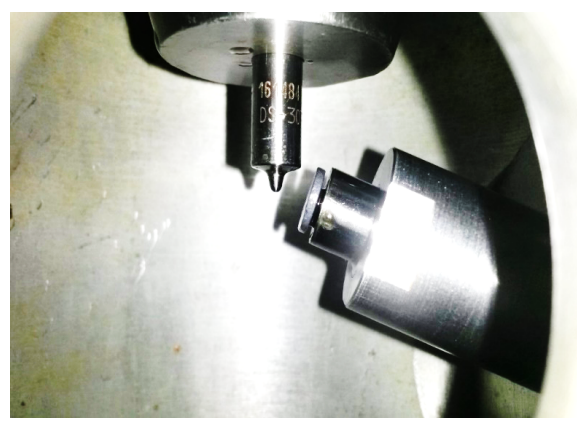

Figure 5: Rate of Momentum set up. 
Payri, R., Hardy, G., Gimeno, J., Bautista, A. (2019). Analysis of counterbore effect in five diesel common rail injectors. Experimental Thermal and Fluid Science, 107(February), 6978. https://doi.org/10.1016/j.expthermflusci.2019.05.008

Table 3: Test matrix for Measurements of Spray G injector.

\begin{tabular}{|l|l|l|l|}
\hline $\begin{array}{l}\text { Back Pressure } \\
(\text { bar })\end{array}$ & $\begin{array}{l}\text { Injection pressure } \\
(\text { bar })\end{array}$ & $\begin{array}{l}\text { Energising Time } \\
(\mathrm{ms})\end{array}$ & $\begin{array}{l}\text { Repetitions for } \\
\text { point tested }\end{array}$ \\
\hline $20 / 45$ & $400 / 800 / 1200 / 1600 / 2000$ & 1.5 & 10 \\
\hline
\end{tabular}

\subsection{Visualization vessel}

For the second part, a non-evaporative visualization vessel was used to record the sprays. The imaging technique used was Mie-scattering. It consists of illuminating the fuel droplets with a light source and collecting the scattered light with a camera. It allows the visualization of the fuel spray liquid phase. Since it is measured in non-evaporative conditions, it can be obtained the fuel liquid penetration and angle of the spray plumes. The complete description of the scattering phenomenon is described in $[\underline{6}$. The test matrix measured in this experiment is shown in Table 3 . The hardware used was two light sources 2Xe$\operatorname{arc}(1000 \mathrm{~W})$, and the camera was a Photron Fastcam SA-5. The images were captured at a frame rate of $28 \mathrm{k}$ fps, using a shutter speed of $16.60 \mu \mathrm{s}$, allowing to capture an area of interest of $82 \times 72 \mathrm{~mm}$, which is enough to capture these developed sprays. Figure 6 shows a picture of the setup.

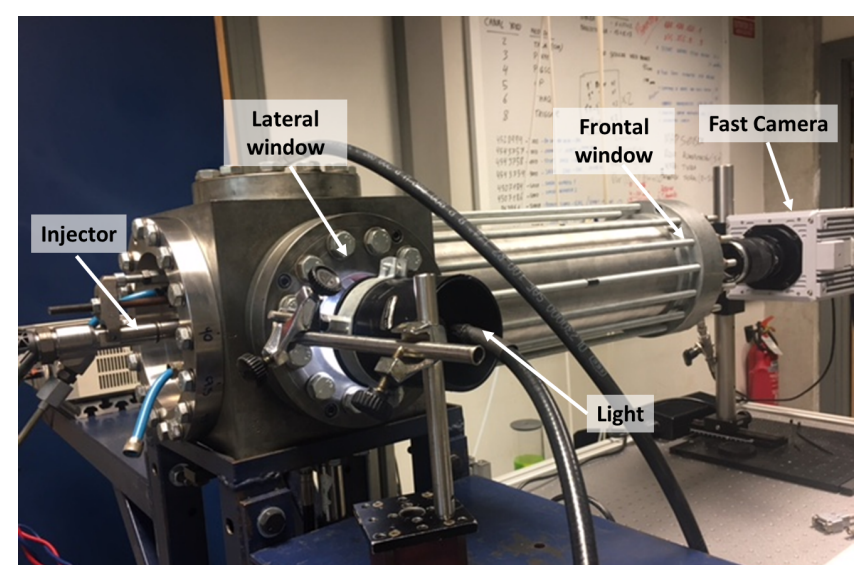

Figure 6: Visualization MIE set up.

The image processing is one of an essential part of any visualization data 
Payri, R., Hardy, G., Gimeno, J., Bautista, A. (2019). Analysis of counterbore effect in five diesel common rail injectors. Experimental Thermal and Fluid Science, 107(February), 6978. https://doi.org/10.1016/j.expthermflusci.2019.05.008

analysis. The processing methodology followed is described in 5. Each image is processed using an algorithm that detects the spray boundary and computes its associated properties. The algorithms are optimized for detection performance of MIE scattering images which is described in detail in [6]. The critical information obtained from the visualization technique for injector comparison are Spray penetration and spray angle. Figure 7 represents the steps to process each image. The error associated with this technique is explained in [6].

- Spray penetration: The liquid penetration in Mie scattering images is calculated by detecting the pixel on the contour that is the furthest from the outlet orifice of the nozzle. Therefore, it is the axial distance from the injector outlet to the furthest point.

- Spray angle: The spray angle from visualization data can be obtained in several ways once the contour has been detected. The different criteria can produce substantial differences in the resulting spreading angle, so it is essential to indicate the selection of one over the others. In this work the criteria considered was Fixed Origin [6], in which the origin is fixed, and then two lines are adjusted with using a weighted average of each point of the contour defined in polar coordinates.

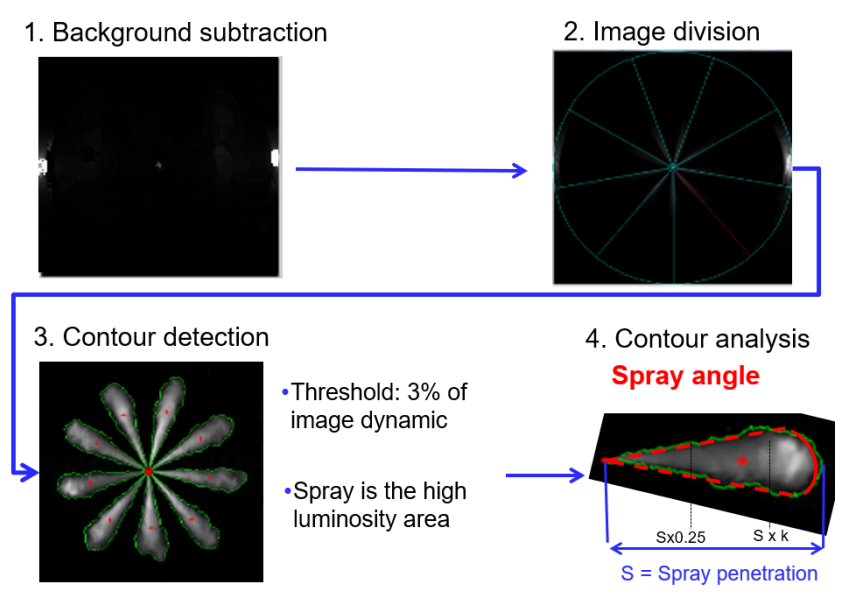

Figure 7: Image Processing. 
Payri, R., Hardy, G., Gimeno, J., Bautista, A. (2019). Analysis of counterbore effect in five diesel common rail injectors. Experimental Thermal and Fluid Science, 107(February), 6978. https://doi.org/10.1016/j.expthermflusci.2019.05.008

\section{Results and discussion}

This section presents a comparison between the five injectors. The discussion is divided between hydraulic comparison, where injection rate and momentum results are presented, and visualization comparison, where macro characteristics of the sprays in non-evaporative conditions are shown.

\subsection{Hydraulic comparison}

\subsubsection{Rate of injection}

Measurements of the rate of injection were performed for all the injectors covering the test matrix. As mentioned before, the injection temperature was kept constant at $70^{\circ} \mathrm{C}$ thanks to the thermo-regulator. From the injection rate signal, a value of stabilized mass flow is obtained, averaging the moment when the needle is completely lifted, and the flow is only constrained by the nozzle orifices.

In Figure 8, it can be observed the different values of stabilized mass flow for the five injectors. It can be appreciated that the original nozzle and the L0.3D3.5 nozzle have the minimum values. The nozzle L0.15D3.5 have an intermedium value and the nozzles L0.4D3.5, and L0.4D2 have the maximum values. Therefore, it was observed that greater counterbore depth increases the stabilized mass flow. The reason possibly lies in that there probably are slightly different orificies outlet diameters for the modified injectors, as it would be explored in section 3.1.3. Also, the figure reported that the stabilized mass flow is proportional to the injection pressure which indicates that there is no cavitation in the range of pressures tested.

\subsubsection{Rate of momentum}

For this experiment, it was measured three of the 8 orifices of each injector. Precisely, it was measured ROM for the orifices 1,3 and 5. Results reported that little variability was found between them as depicted in Figure 9, so it is assumed that all orifices contribute the same to the ROM. Similar results were obtained for the rest of the injectors. 
Payri, R., Hardy, G., Gimeno, J., Bautista, A. (2019). Analysis of counterbore effect in five diesel common rail injectors. Experimental Thermal and Fluid Science, 107(February), 6978. https://doi.org/10.1016/j.expthermflusci.2019.05.008

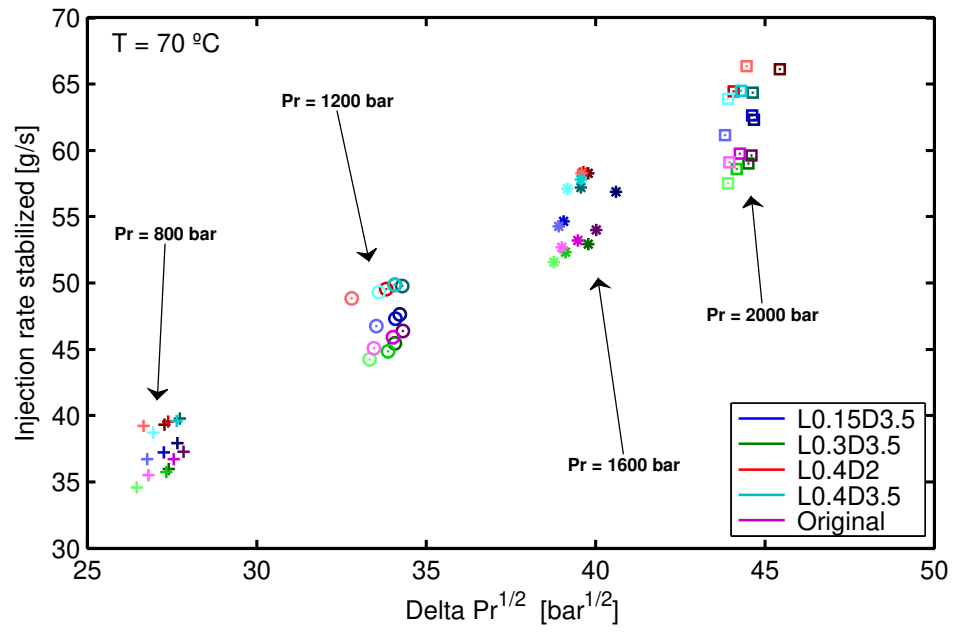

Figure 8: Stabilized mass flow for the 5 injectors. Darker dots means higher $P_{b a c k}(80,45,20$ bar).

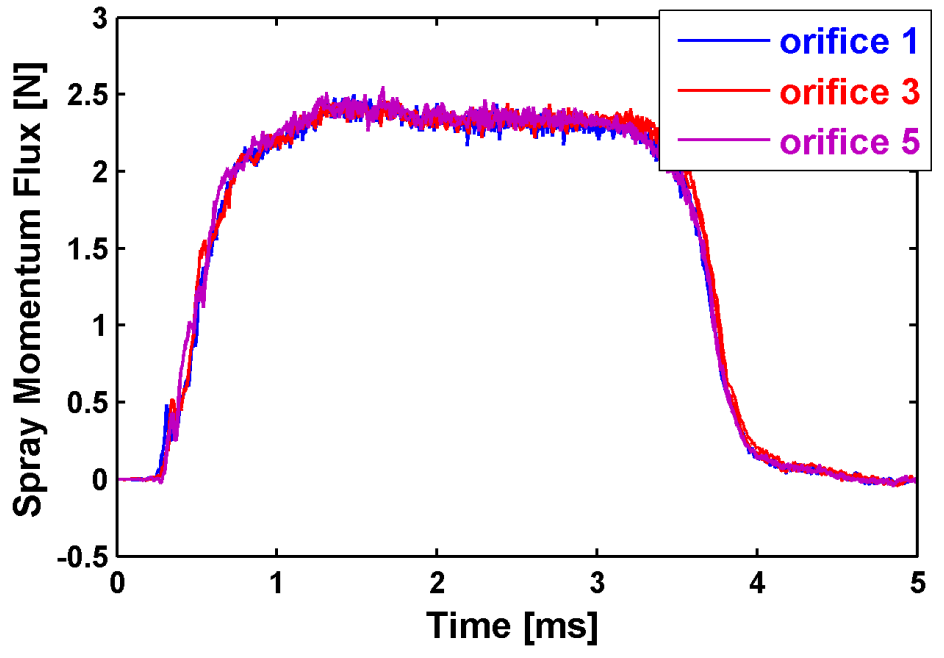

Figure 9: Variability between holes (original injector).

Figure 10 shows the effects of the counterbores on the ROM. The stabilized rate of momentum tendency is similar to the one found in ROI results. It is observed that the original nozzle and the L0.3D3.5 nozzle have the minimum values. The nozzle L0.15D3.5 have an intermedium value. Finally, the nozzles L0.4D3.5 and L0.4D2 have the maximum values of spray momentum. No def- 
Payri, R., Hardy, G., Gimeno, J., Bautista, A. (2019). Analysis of counterbore effect in five diesel common rail injectors. Experimental Thermal and Fluid Science, 107(February), 6978. https://doi.org/10.1016/j.expthermflusci.2019.05.008

inite conclusion could be ascribed to the geometry of the counterbore to this point. However, in the next section where nozzle coefficients are examined some conclusions could be extracted.

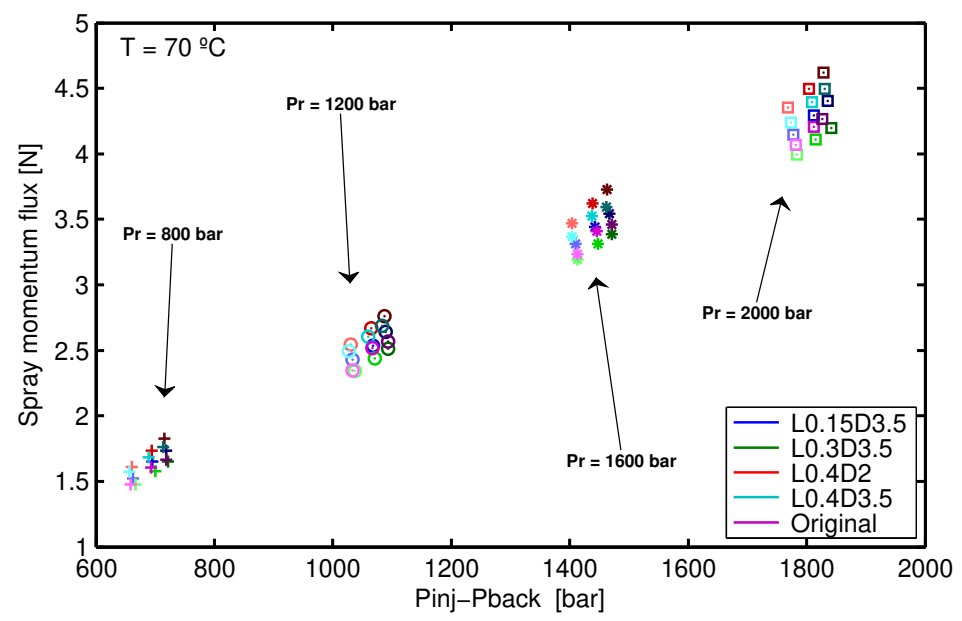

Figure 10: Stabilized Rate of momentum of the five injectors. Darker dots means higher $P_{b a c k}$ (80, 45, 20 bar).

\subsubsection{Nozzle coefficients}

Using the experimental data from ROI and ROM, other parameters that indicate the performance of the nozzle could be obtained to achieve a more in-depth comparison between injectors [40. For this purpose, the discharge coefficient, effective velocity, and effective diameter will be analyzed.

Figure 11 shows the discharge coefficient parameter for the five injectors against the square root of delta $\mathrm{P}$. It is calculated as shown in eq 2 , where $A_{0}$ is the total outlet area computed using diameter from drawings.

$$
C_{d}=\frac{\dot{m}_{f}}{A_{0} \sqrt{2 \cdot \rho_{f} \cdot \Delta p}}
$$

The values of $C_{d}$ cannot be greater than 1 ; therefore, there are some differences between the specification from drawings of the nozzle holes and the real ones, however, in this case, we are not interested in the value itself but its 
Payri, R., Hardy, G., Gimeno, J., Bautista, A. (2019). Analysis of counterbore effect in five diesel common rail injectors. Experimental Thermal and Fluid Science, 107(February), 6978. https://doi.org/10.1016/j.expthermflusci.2019.05.008

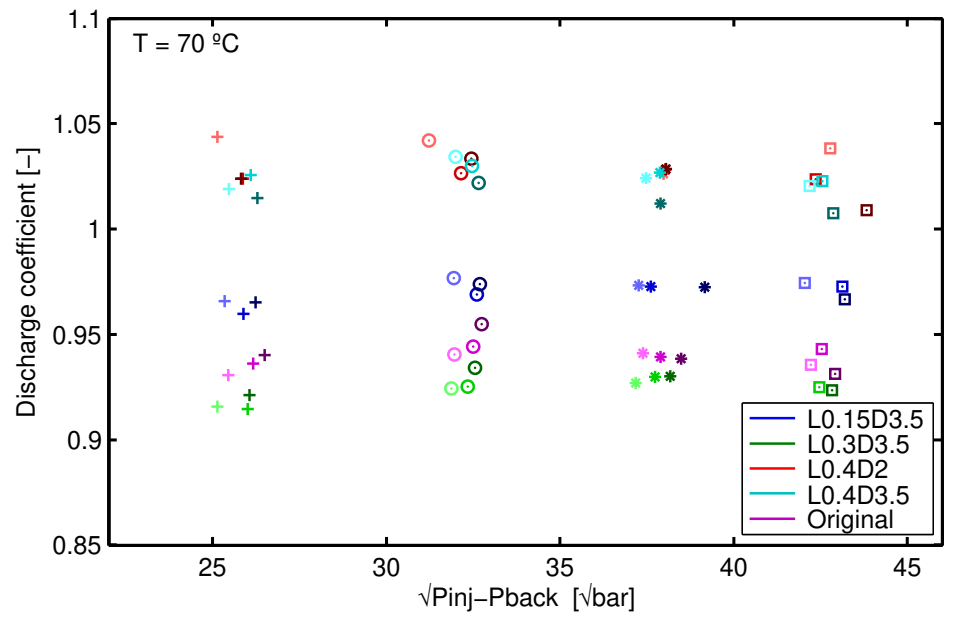

Figure 11: Discharge coefficient.

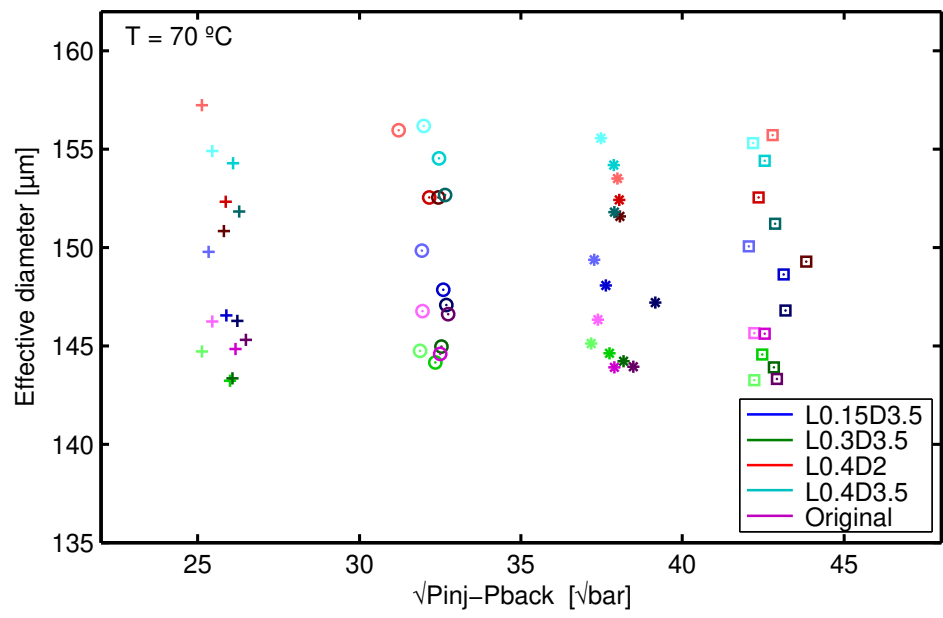

Figure 12: Effective diameter of the five injectors.

comparison between the injectors. It can be seen that the discharge coefficient value is kept almost constant through all the injection pressures which indicate no change of nozzle regime in the range tested. Consequently, the same effective area is used by each injector. It can be observed that nozzle L0.4D3.5 and L0.4D2 have the largest $C_{d}$, the nozzle L0.15D3.5 have an intermedium value, and the nozzles L0.3D3.5 and the original have the lowest $C_{d}$. It designates that 
Payri, R., Hardy, G., Gimeno, J., Bautista, A. (2019). Analysis of counterbore effect in five diesel common rail injectors. Experimental Thermal and Fluid Science, 107(February), 6978. https://doi.org/10.1016/j.expthermflusci.2019.05.008

a larger effective area is used for the nozzles with the counterbore. Figure 12 report the same tendency of the nozzles this time with the effective diameter $\left(D_{e f}\right)$. It was found slightly higher effective diameter values than the originals from the nozzle, so probably the counterbore enhanced to some extent the mass injected.

The authors suspect that the outlet section of the orifices is no equal for all injectors. Modifications were made to the original injectors orifices whose k-factor indicates a positive conical shape. Therefore, the exit diameter would depend on the depth of the recess as shown in Figure 13 . Assuming this is true and depending on the depth of the counterbore, a corrected exit diameter was computed for each injector in order to compare those accurately.

The corrected diameters are obtained from knowing the total original orifice length and applying Eq. 1, in which it is assumed a proportional decrease of the orifice section. To obtain the exit diameter for a given orifice the distance of the recess is subtracted from the original length, and by using the k-factor equation, the corrected outlet diameter is computed.

The new diameters were bigger, although only $4.3 \%$ bigger when looking at the worst case with the deeper recess. When computing the new discharge coefficients using the corrected diameters reasonable values $(<1)$ where obtained (see Figure 14, which indicates diameters closer to reality. The results indicate that the diameter of the recess affects the $C_{d}$ (nozzles with D3.5). However, there is not a clear tendency can be induced when looking at the depth of counterbore. Differences in external flow would add more information.

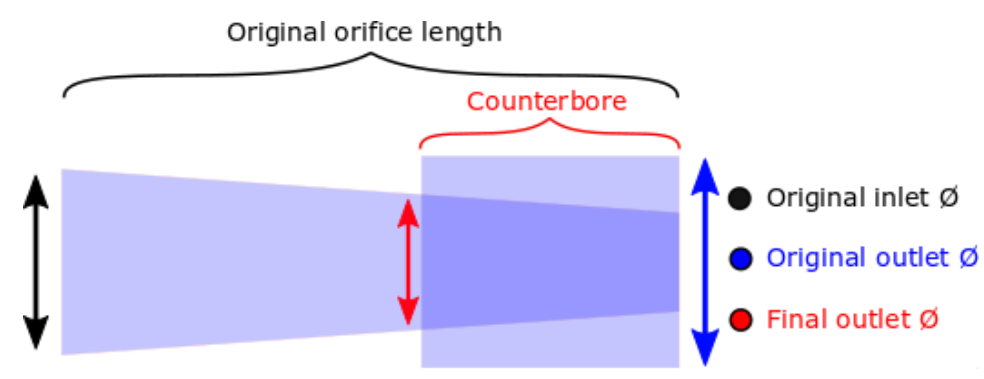

Figure 13: Sketch of the nozzle orifice. 
Payri, R., Hardy, G., Gimeno, J., Bautista, A. (2019). Analysis of counterbore effect in five diesel common rail injectors. Experimental Thermal and Fluid Science, 107(February), 6978. https://doi.org/10.1016/j.expthermflusci.2019.05.008

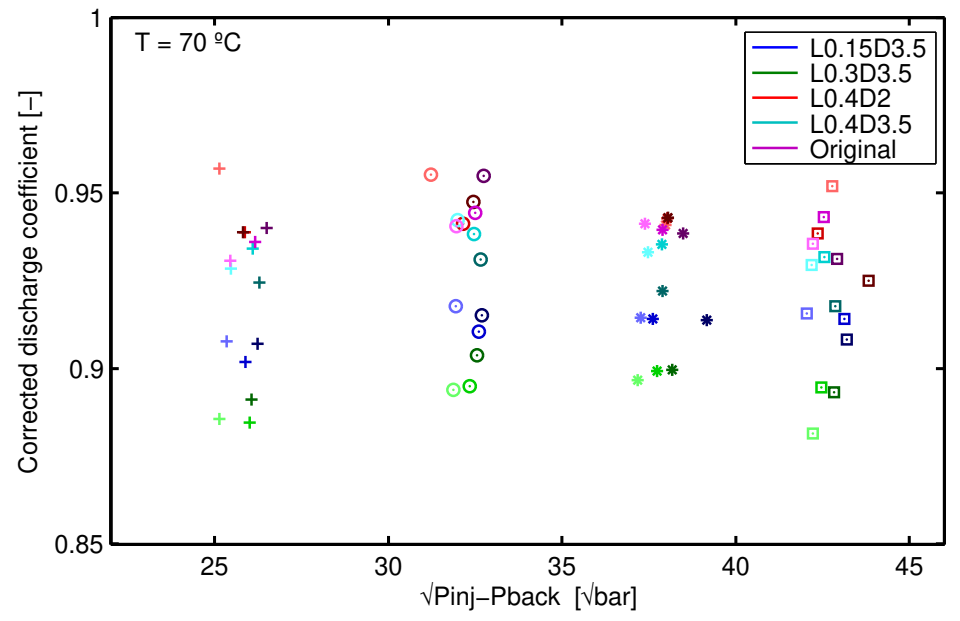

Figure 14: Corrected discharge coefficient.

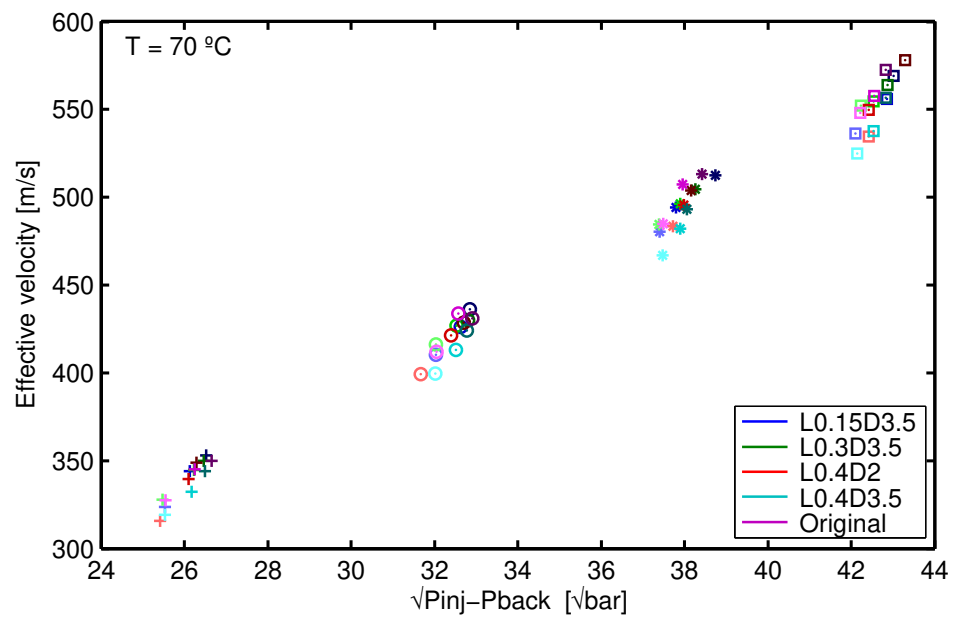

Figure 15: Effective velocity for the 5 injectors.

The Figure 15 depicts the effective velocity against the delta P. It is calculated as shown in equation 3 .

$$
u_{e f f}=\frac{\dot{M}_{f}}{\dot{m}_{f}}
$$

This theoretical velocity is computed from the ROI and ROM data. It 
Payri, R., Hardy, G., Gimeno, J., Bautista, A. (2019). Analysis of counterbore effect in five diesel common rail injectors. Experimental Thermal and Fluid Science, 107(February), 6978. https://doi.org/10.1016/j.expthermflusci.2019.05.008

Table 4: Hydraulics results. Depth effect.

\begin{tabular}{|c|c|c|c|c|c|c|c|}
\hline Injector & $\begin{array}{c}\text { Times the } \phi \\
\text { of the } \\
\text { original }\end{array}$ & $\begin{array}{c}\text { \% } \\
\text { Depth }\end{array}$ & $\begin{array}{c}\text { Mean } \\
D_{\text {ef }} \\
(\mu \mathbf{m})\end{array}$ & $\begin{array}{c}D_{e f} \\
\text { variation } \\
(\%)\end{array}$ & $\begin{array}{c}\text { Variation in } \\
\text { mass flow (\%) }\end{array}$ & $\begin{array}{c}\text { Variation in } \\
\text { momentum flux (\%) }\end{array}$ & $\begin{array}{c}\text { Variation in } \\
\text { Velocity (\%) }\end{array}$ \\
\hline Original & 0 & 0 & 144.7 & 0 & 0 & 0 & 0 \\
\hline L0.15D3.5 & 3.5 & 15 & 144.1 & -0.4 & -0.7 & -3 & -2.3 \\
\hline L0.3D3.5 & 3.5 & 30 & 147.7 & +2.0 & +4.2 & +1.7 & -3.9 \\
\hline L0.4D3.5 & 3.5 & 40 & 154.4 & +6.3 & +7.8 & +3.4 & -5.6 \\
\hline
\end{tabular}

decreases mostly for the nozzle L0.4D3.5. Nozzle L0.4D2 is the next lowest. However, the rest are together around the value of the original. The reduction of effective velocity may be ascribed to the increase of mass flow since the nozzles with higher mass flow have the lowest effective velocity. By the continuity equation, this reduction can be explained if it is assumed that the injected mass flow is kept approximately the same.

A linear fit was done for the experimental data for all the cases using the least squares fit to quantify the differences in the parameters analyzed. The increment in slope and abscissa can be translated to a difference in percentage, which is reflected in the following tables.

First, in Table 4 is analyzed the influence of the depth of the recess in the results obtained:

Nozzles with deeper counterbore showed higher injected mass per cycle, so the depth of the recess is increasing the mass flow rate (except L0.15D3.5 which presented almost the same value as the original). The exact relation for the variation of momentum flux is not clear since a tendency cannot be inferred. The nozzle L0.15D3.5 is an exception again. Nevertheless, for the velocity, it is reduced when the counterbore is deeper. The exception of the nozzle L0.15D3.5 is attributed to imperfections and uncertainties in the geometry of the orifices. The use of X-rays or silicon technique could provide exact geometry information to draw a reason for this injector behavior.

Secondly, in Table 5 is analyzed the influence of the diameter of the recess in the results obtained:

As it can be observed in Table 5 , increasing diameter of the recess would 
Payri, R., Hardy, G., Gimeno, J., Bautista, A. (2019). Analysis of counterbore effect in five diesel common rail injectors. Experimental Thermal and Fluid Science, 107(February), 6978. https://doi.org/10.1016/j.expthermflusci.2019.05.008

Table 5: Hydraulics results. Diameter effect.

\begin{tabular}{|c|c|c|c|c|c|c|c|}
\hline Injector & $\begin{array}{c}\text { Times the } \\
\phi \text { of the } \\
\text { original }\end{array}$ & $\begin{array}{c}\text { \% } \\
\text { Depth }\end{array}$ & $\begin{array}{c}\text { Mean } \\
D_{e f} \\
(\mu \mathbf{m})\end{array}$ & $\begin{array}{c}D_{e f} \\
\text { variation } \\
(\%)\end{array}$ & $\begin{array}{c}\text { Variation in } \\
\text { mass flow (\%) }\end{array}$ & $\begin{array}{c}\text { Variation in } \\
\text { momentum flux (\%) }\end{array}$ & $\begin{array}{c}\text { Variation in } \\
\text { Velocity (\%) }\end{array}$ \\
\hline Original & 0 & 0 & 144.7 & 0 & 0 & 0 & 0 \\
\hline L0.4D2 & 2 & 40 & 152.5 & +5.1 & +7.8 & +6.8 & -1.9 \\
\hline L0.4D3.5 & 3.5 & 40 & 154.4 & +6.3 & +7.8 & +3.4 & -5.6 \\
\hline
\end{tabular}

decrease the effective velocity. However, the variation of ROM does not present a clear tendency, and probably other variables are affecting its change so no conclusions can be obtained. Looking at the variation in mass flow, the increment to respect to the original is the same for each nozzle. Therefore, it can be stated that the diameter of the counterbore does not affect the mass flow for the same depth.

\subsection{Visualization comparison}

As mentioned in the methodology section, the technique used to analyze the non-evaporative spray was Mie-Scattering. The videos recorded were processed following the procedure explained in detail in [6] : background subtraction, image division, contour detection (by thresholding) and finally contour analysis. Measurements of spray penetration and spray angle were acquired for each injector and orifice. Each spray is processed separately for each repetition and time step; however, the results shown in this section are the averaged value of measured liquid spray penetration for all spray plumes and repetitions, in a representative population of the whole data.

\subsubsection{Spray penetration}

Figure 16 illustrates the spray penetration for different pressures for the original nozzle, the standard deviation is represented with the shades. As it can be noticed, there is little dispersion between repetitions. It was observed similar variation for all the injectors.

Figure 17 shows an example of the penetration of the sprays in function of time for the case of 400 bar of injection pressure and 20 bar of back pressure. It 
Payri, R., Hardy, G., Gimeno, J., Bautista, A. (2019). Analysis of counterbore effect in five diesel common rail injectors. Experimental Thermal and Fluid Science, 107(February), 6978. https://doi.org/10.1016/j.expthermflusci.2019.05.008

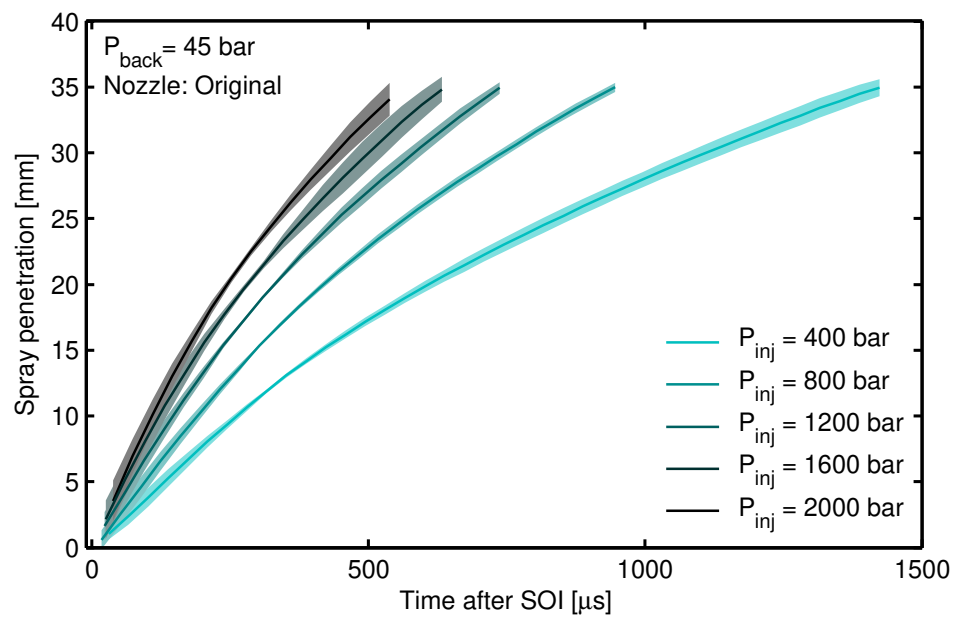

Figure 16: Spray penetration against time, shot to shot variation.

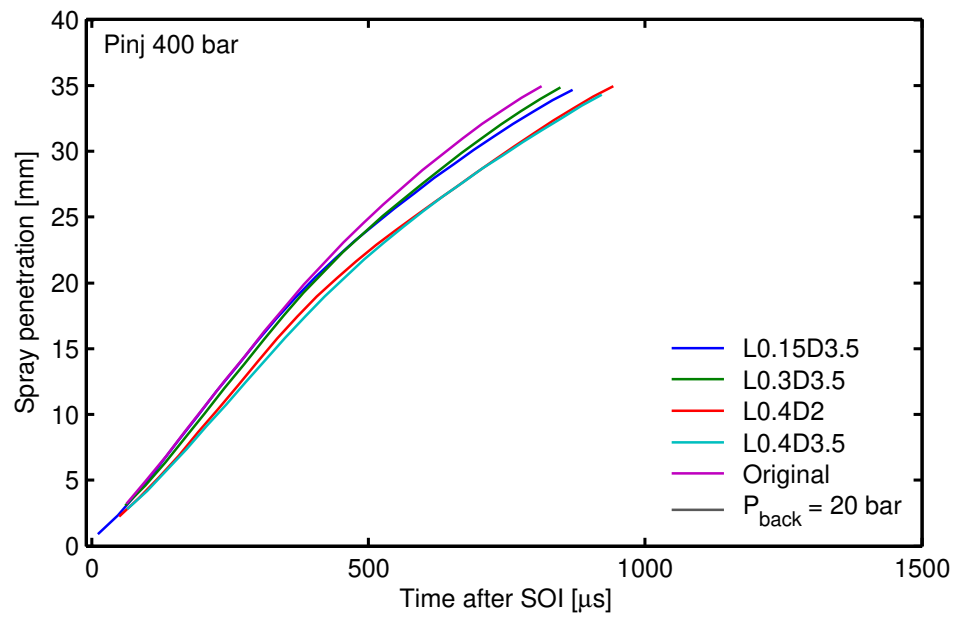

Figure 17: Spray penetration against time, injectors comparison.

is detected that the penetration decreases for any modified injector for a given time. For example, at $500 \mu$ s the original injector has the highest penetration, whereas L0.15D3.5 and L0.3D3.5 have 4.1\% lower, and L0.4D3.5 and L0.4D2 have $12.5 \%$ lower. It is coherence with the results obtained in the hydraulic characterization since for the injector that has the lowest penetration has the 
Payri, R., Hardy, G., Gimeno, J., Bautista, A. (2019). Analysis of counterbore effect in five diesel common rail injectors. Experimental Thermal and Fluid Science, 107(February), 6978. https://doi.org/10.1016/j.expthermflusci.2019.05.008

lowest effective velocities.

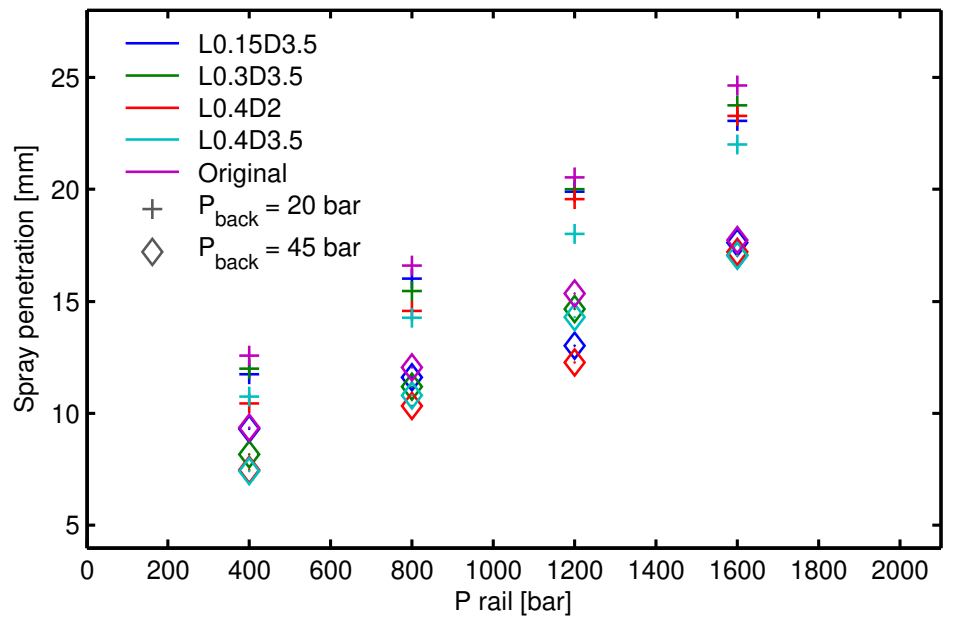

Figure 18: Spray penetration at $250 \mu \mathrm{s}$.

Figure 18, depicts the penetration at $250 \mu$ s for different injection pressure and the two back pressure 20 and 45 . For this time the penetration error was below $1.5 \%$. It is observed less penetration for nozzles with a deeper recess. Moreover, the differences are more significant for lower injection pressures. On the contrary, for higher injection pressure the penetration differences are smaller, so the points collide together. Finally, it has been observed that maximum average penetration varies between injectors. From the shot to shot analysis showed little dispersion on penetration. Higher injection pressure increases the slope of the penetration whereas higher back pressure decreases it as expected. Nozzles with the deepest recess (L0.4) have the lowest penetration at lower injection pressures. Lastly, at higher injection pressure all the nozzles behave similarly.

\subsubsection{Spray angle}

As commented in the previous section, the criteria for angle calculation used was fixed origin since it was more robust for a broader range of injection pressure because of the longer stabilized values. 
Payri, R., Hardy, G., Gimeno, J., Bautista, A. (2019). Analysis of counterbore effect in five diesel common rail injectors. Experimental Thermal and Fluid Science, 107(February), 6978. https://doi.org/10.1016/j.expthermflusci.2019.05.008
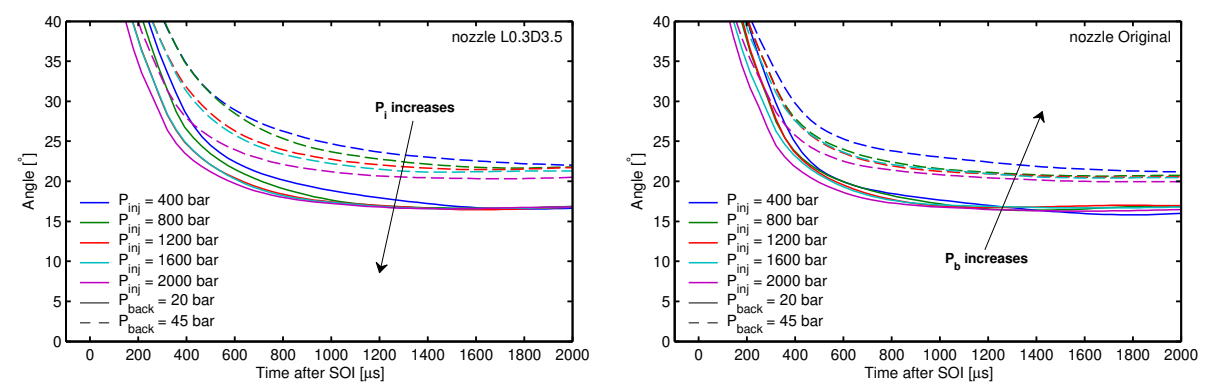

Figure 19: Effects of $P_{r}$ and $P_{b a c k}$ over the spray angle.

Figure 19 shows how the injection pressure and back pressure affect the spray angle. It is observed an expected behavior of spray angle with the variation of both parameters. For higher $P_{r}$ the angle decreases because the spray has more momentum in the hole direction. On the other hand, higher $P_{b a c k}$ increases the spray angle, because it increases the air density and also the resistance to advance the spray. This behavior is present in all the injectors.

Next, it is aimed to set criteria for spray angle comparison between the nozzles using the information from the conditions tested. Figure 20 depicts an example of spray angle against time for $P_{r}=400$ bar. It can be observed that in the first moments of injection the angle is relatively large because of the criteria calculation. Once the spray is developed the angle achieve a comparatively stabilized value.

The approach to compare the nozzle analyses the value of the angles when those are stabilized. The value is calculated averaging inside a chosen time window. The window that the authors believe that captures the stabilized value are between 1.6 and 2 ms. Figure 21 shows the stabilized values using this approach. It can be seen that the angles are affected by the nozzle geometry. More air entrainment would be translated into higher angles. The results report that at higher $P_{r}$ the influence of the counterbore on the angles is less evident.

Next, in Table 6 and Table 7 is presented a summary of results to evaluate easier the effect of depth and diameter in the nozzles and understand its effect separately. For the stabilized angle for each back pressure, an average is 
Payri, R., Hardy, G., Gimeno, J., Bautista, A. (2019). Analysis of counterbore effect in five diesel common rail injectors. Experimental Thermal and Fluid Science, 107(February), 6978. https://doi.org/10.1016/j.expthermflusci.2019.05.008

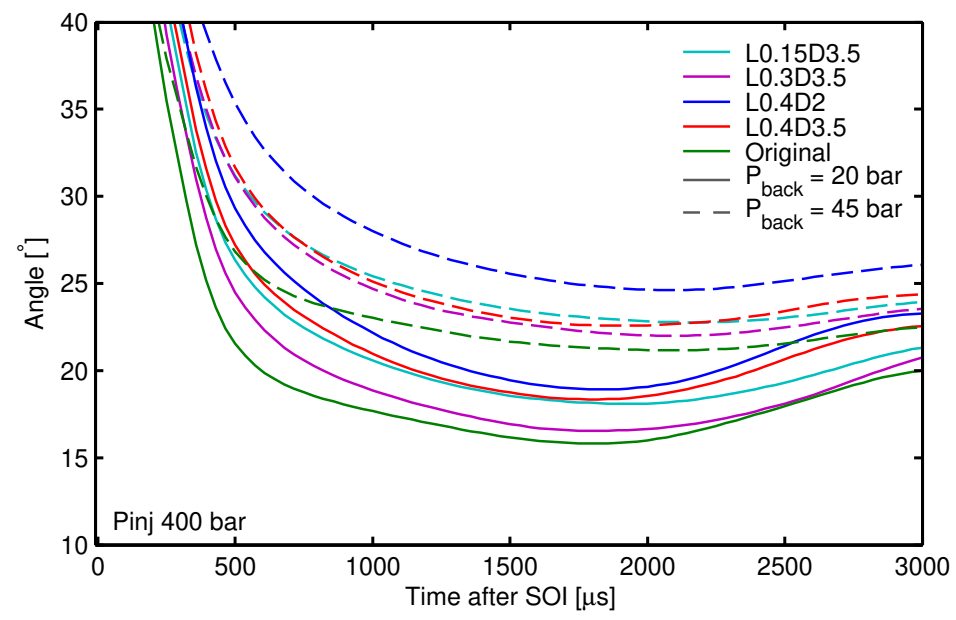

Figure 20: Spray angle against time for $P_{r}=400$ bar and $P_{b a c k}=20$ and 45 .
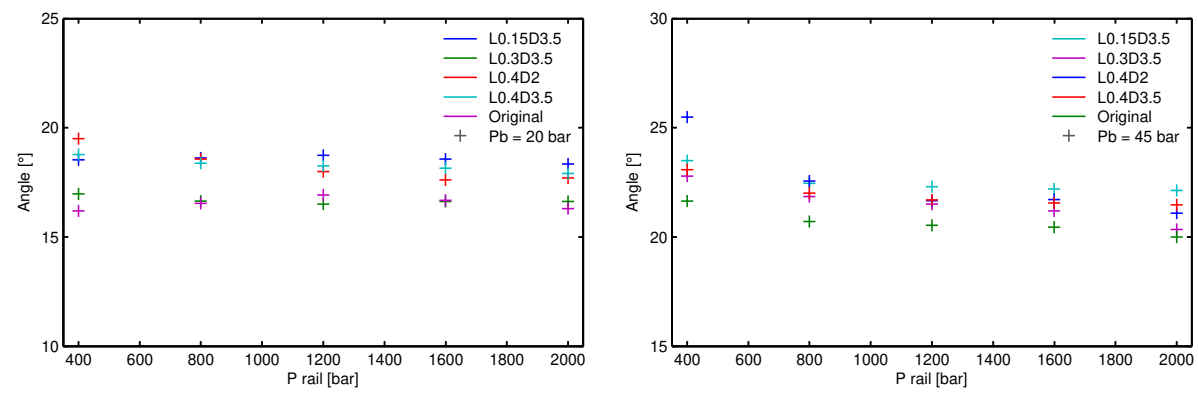

Figure 21: Stabilized spray angle values.

computed. The error of the stabilized angle was found to be around $3 \%$.

Table 6 analyzes the effect of the depth of the counterbore. It reports that the stabilized angle increases with the depth for both back pressures (considering L0.4 and L0.3 nozzles have similar angles). The increase is not linear since no proportional increase with the depth is observed. In the case of $P_{b a c k}=20$ bar, a depth of 0.15 of the total length produces almost no variation, whereas at 0.3 and 0.4 have an increase of $11.47 \%$ and $9.27 \%$ respectively. This behavior could be produced due to at 0.15 the spray is not influenced by the counterbore wall. However, from 0.3 the spray could be hitting the edge of the recess at the exit of the nozzle which causes widening of the jet. At $45 P_{b a c k}$ the argument 
Payri, R., Hardy, G., Gimeno, J., Bautista, A. (2019). Analysis of counterbore effect in five diesel common rail injectors. Experimental Thermal and Fluid Science, 107(February), 6978. https://doi.org/10.1016/j.expthermflusci.2019.05.008

is similar though the 0.15 influence this time the angle of the spray. It may be because at higher $P_{\text {back }}$ the density increases which raises the resistance for the jet to advance. It produces a broader plume from first instances of penetration, which facilitates the counterbore to influence in the angle. These results are in coherence with the hydraulic characterization performed, where it showed lower exits velocities however higher mass flow.

Table 7 reports the results of the effect of the diameter in the angle of the spray. It can be observed that for both $P_{b a c k}$ the angle increases with the diameter comparing to the original nozzle, albeit there is not any clear trend which indicates the influence of the size of the diameter. Results for the lower $P_{b a c k}$ gives higher increment than at high $P_{b a c k}$. The effect of the diameter is detected to be less important than the effect of the depth of the recess since between the two injectors studied there are not many differences.

Table 6: Effect of depth. First angle approach.

\begin{tabular}{|l|l|l|l|l|l|l|l|l|l|l|}
\hline Injector & $\begin{array}{l}\text { Times } \\
\text { the } \phi \text { of } \\
\text { the } \\
\text { original }\end{array}$ & $\begin{array}{l}\text { \% } \\
\text { Depth }\end{array}$ & $\begin{array}{l}\text { Mean } \\
D_{\text {ef }} \\
(\mu \mathrm{m})\end{array}$ & $\begin{array}{l}\text { Stab. } \\
\text { angle } \\
P_{\text {back }} \\
\mathbf{2 0}\end{array}$ & $\begin{array}{l}\text { Variation } \\
(\%)\end{array}$ & $\begin{array}{l}\text { Stab. } \\
\text { angle } \\
P_{\text {back }} \\
\mathbf{4 5}\end{array}$ & $\begin{array}{l}\text { Variation } \\
(\%)\end{array}$ & $\begin{array}{l}\text { Variation } \\
\text { in mass } \\
\text { flow (\%) }\end{array}$ & $\begin{array}{l}\text { Variation in } \\
\text { momentum } \\
\text { flux (\%) }\end{array}$ & $\begin{array}{l}\text { Variation } \\
\text { in } \\
\text { Velocity (\%) }\end{array}$ \\
\hline Original & 0 & 0 & 144.7 & $16.71 \pm 0.50$ & 0 & $20.56 \pm 0.62$ & 0 & 0 & 0 & 0 \\
\hline L0.15D3.5 & 3.5 & 0.15 & 144.1 & $16.59 \pm 0.50$ & -0.74 & $21.51 \pm 0.65$ & +4.63 & -0.7 & -3 & -2.3 \\
\hline L0.3D3.5 & 3.5 & 0.3 & 147.7 & $18.63 \pm 0.56$ & +11.47 & $22.31 \pm 0.67$ & +8.53 & +4.2 & +1.7 & -3.9 \\
\hline L0.4D3.5 & 3.5 & 0.4 & 154.4 & $18.26 \pm 0.55$ & +9.27 & $21.74 \pm 0.65$ & +5.75 & +7.8 & +3.4 & -5.6 \\
\hline
\end{tabular}

Table 7: Effect of diameter. First angle approach.

\begin{tabular}{|l|l|l|l|l|l|l|l|l|l|l|}
\hline Injector & $\begin{array}{l}\text { Times } \\
\text { the } \phi \text { of } \\
\text { the } \\
\text { original }\end{array}$ & $\begin{array}{l}\text { \% } \\
\text { Depth }\end{array}$ & $\begin{array}{l}\text { Mean } \\
D_{\text {ef }} \\
(\mu \mathbf{m})\end{array}$ & $\begin{array}{l}\text { Stab. } \\
\text { angle } \\
P_{\text {back }} \\
\mathbf{2 0}\end{array}$ & $\begin{array}{l}\text { Variation } \\
(\%)\end{array}$ & $\begin{array}{l}\text { Stab. } \\
\text { angle } \\
P_{\text {back }} \\
\mathbf{4 5}\end{array}$ & $\begin{array}{l}\text { Variation } \\
(\%)\end{array}$ & $\begin{array}{l}\text { Variation } \\
\text { in mass } \\
\text { flow (\%) }\end{array}$ & $\begin{array}{l}\text { Variation in } \\
\text { momentum } \\
\text { flux (\%) }\end{array}$ & $\begin{array}{l}\text { Variation } \\
\text { in } \\
\text { Velocity (\%) }\end{array}$ \\
\hline Original & 0 & 0 & 144.7 & $16.71 \pm 0.50$ & 0 & $20.56 \pm 0.62$ & 0 & 0 & 0 & 0 \\
\hline L0.4D2 & 2 & 0.4 & 152.5 & $18.05 \pm 0.54$ & +8.01 & $21.98 \pm 0.66$ & +6.88 & +7.8 & +6.8 & -1.9 \\
\hline L0.4D3.5 & 3.5 & 0.4 & 154.4 & $18.26 \pm 0.55$ & +9.27 & $21.74 \pm 0.65$ & +5.75 & +7.8 & +3.4 & -5.6 \\
\hline
\end{tabular}

\section{Conclusions}

This work has presented a study about the effect of the counterbore in diesel injector nozzles. Five equal injectors were used for the experiments. The nozzle 
Payri, R., Hardy, G., Gimeno, J., Bautista, A. (2019). Analysis of counterbore effect in five diesel common rail injectors. Experimental Thermal and Fluid Science, 107(February), 6978. https://doi.org/10.1016/j.expthermflusci.2019.05.008

of four of them was modified adding a counterbore to the orifices. Each injector had a different design varying the diameter and depth of the recess.

The rate of injection and momentum test rig were used to perform experiments to characterize the hydraulic behavior of the injectors. Results from this part report slightly higher ROI and ROM values for injectors with counterbore compared with the original nozzle (except for injector L0.15D3.5 which reported lower, as stated in section 3.1.3. It was observed for the modified injectors that the effective velocity decreases when diameter or depth of recess increases. Moreover, it was realized that there could be a possible uncertainty of the orifice diameters due to the $\mathrm{k}$ factor on the modified injectors. Looking at nozzle coefficient, Discharge coefficients results suggest there are bigger orifices diameters than the ones indicated. Also, effective diameters calculated are more significant than expected orifice diameters form drawings. Perhaps a Silicon or $\mathrm{X}$-rays analysis of the injector nozzles could provide reliable information about the geometry.

Visualization results depicted lower angle and higher penetration for the original nozzle. The modified nozzles, whose hydraulic analysis arose lower effective velocity, presented higher angles and lower penetration which was an expected outcome. Deeper counterbore caused higher angle and lower penetration, nevertheless, the effect of the diameter of the recess on the penetration and the angle seemed to be less critical.

Finally, Differences in all the study are minimal to state a real conclusion. Probably, there are uncertainties about the diameter of the orifices which could lead to a misleading conclusion in the hydraulic characteristics. Future measurements of those could provide more obvious conclusions regarding this part. The presence of counterbore in diesel injector could benefit the air-fuel mixture mostly for more air entrainment, higher angles, and lower penetration. However, the drawback of including the recess is lower exit velocities which could harm the penetration performance at high chamber pressures. 
Payri, R., Hardy, G., Gimeno, J., Bautista, A. (2019). Analysis of counterbore effect in five diesel common rail injectors. Experimental Thermal and Fluid Science, 107(February), 6978. https://doi.org/10.1016/j.expthermflusci.2019.05.008

\section{Acknowledgments}

The authors would like to express their gratitude to the lab technicians Jose Enrique and Omar and to Sai Vinayak and Alejandro Tortosa for their collaboration throughout the experiments. Part of the experimental equipment was purchased with support from Generalitat Valenciana through project IDIFEDER2018 with title "DIAGNOSTICO OPTICO A ALTA VELOCIDAD PARA EL ESTUDIO DE PROCESOS TERMO-FLUIDODINAMICOS EN SISTEMAS DE INYECCION". Finally, they would like to acknowledge the partnership with $\mathrm{CNH}$ industrial.

\section{References}

[1] A. Paykani, A. H. Kakaee, P. Rahnama, R. D. Reitz, Progress and recent trends in reactivity-controlled compression ignition engines, 2016. doi 10 . $1177 / 1468087415593013$.

[2] S. V. Khandal, N. R. Banapurmath, V. N. Gaitonde, S. S. Hiremath, Paradigm shift from mechanical direct injection diesel engines to advanced injection strategies of diesel homogeneous charge compression ignition (HCCI) engines- A comprehensive review, 2017. doi $10.1016 / \mathrm{j} . r s e r$. 2016.11 .058

[3] D. Han, J. Zhai, Y. Duan, C. Wang, Z. Huang, Nozzle effects on the injection characteristics of diesel and gasoline blends on a common rail system, Energy (2018). doi 10.1016/j.energy . 2018.04.039.

[4] T. D. Fansler, S. E. Parrish, Spray measurement technology: a review, Measurement Science and Technology 26 (2015) 012002. doi 10.1088/ 0957-0233/26/1/012002.

[5] R. Payri, J. P. Viera, V. Gopalakrishnan, P. G. Szymkowicz, The effect of nozzle geometry over the evaporative spray formation for three different fuels, Fuel 188 (2017) 645-660. doi 10.1016/j.fuel.2016.06.041. 
Payri, R., Hardy, G., Gimeno, J., Bautista, A. (2019). Analysis of counterbore effect in five diesel common rail injectors. Experimental Thermal and Fluid Science, 107(February), 6978. https://doi.org/10.1016/j.expthermflusci.2019.05.008

[6] R. Payri, J. Gimeno, G. Bracho, D. Vaquerizo, Study of liquid and vapor phase behavior on Diesel sprays for heavy duty engine nozzles, Applied Thermal Engineering 107 (2016) 365-378. doi $10.1016 / j$. applthermaleng.2016.06.159.

[7] R. Payri, S. Molina, F. J. Salvador, J. Gimeno, A study of the relation between nozzle geometry, internal flow and sprays characteristics in diesel fuel injection systems, KSME International Journal 18 (2004) 1222-1235. doi: $10.1007 /$ BF02983297.

[8] Z. Liu, K.-S. Im, Y. Wang, K. Fezzaa, J. Wang, X.-B. Xie, M.-C. Lai, Near-Nozzle Structure of Diesel Sprays Affected by Internal Geometry of Injector Nozzle: Visualized by Single-Shot X-ray Imaging, SAE Technical Paper 2010-01-0877 (2010). doi 10.4271/2010-01-0877.

[9] R. Payri, J. M. García-Oliver, T. Xuan, M. Bardi, A study on diesel spray tip penetration and radial expansion under reacting conditions, Applied Thermal Engineering 90 (2015) 619-629. doi:10.1016/j . applthermaleng. 2015.07 .042

[10] C. Yao, P. Geng, Z. Yin, J. Hu, D. Chen, Y. Ju, Impacts of nozzle geometry on spray combustion of high pressure common rail injectors in a constant volume combustion chamber, Fuel 179 (2016) 235-245. doi $10.1016 / j$. fuel.2016.03.097.

[11] R. Payri, F. J. Salvador, J. Gimeno, J. De la Morena, Effects of nozzle geometry on direct injection diesel engine combustion process, Applied Thermal Engineering 29 (2009) 2051-2060. doi:10.1016/j.applthermaleng.2008. 10.009 .

[12] S. Som, D. E. Longman, A. I. Ramirez, S. K. Aggarwal, in: Fuel Injection in Automotive Engineering, InTech, 2012, pp. 112-126. doi 10.5772/38900.

[13] D. Li, S. Liu, Y. Wei, R. Liang, Y. Tang, Numerical investigation on transient internal cavitating flow and spray characteristics in a single-hole diesel 
Payri, R., Hardy, G., Gimeno, J., Bautista, A. (2019). Analysis of counterbore effect in five diesel common rail injectors. Experimental Thermal and Fluid Science, 107(February), 6978. https://doi.org/10.1016/j.expthermflusci.2019.05.008

injector nozzle: A 3D method for cavitation-induced primary break-up, Fuel (2018). doi:10.1016/j.fuel.2018.06.103.

[14] X. Leng, Y. Jin, Z. He, Q. Wang, M. Li, W. Long, Effects of V-type intersecting hole on the internal and near field flow dynamics of pressure atomizer nozzles, International Journal of Thermal Sciences (2018). doi $10.1016 / j . i j t h e r m a l s c i .2018 .04 .016$.

[15] L. Lešnik, B. Kegl, G. Bombek, M. Hočevar, I. Biluš, The influence of innozzle cavitation on flow characteristics and spray break-up, Fuel (2018). doi $10.1016 / j$. fuel.2018.02.144.

[16] J. Cui, H. Lai, K. Feng, Y. Ma, Quantitative analysis of the minor deviations in nozzle internal geometry effect on the cavitating flow, Experimental Thermal and Fluid Science (2018). doi:10.1016/j.expthermflusci.2018. 02.002

[17] M. G. De Giorgi, D. Fontanarosa, A. Ficarella, Characterization of cavitating flow regimes in an internal sharp-edged orifice by means of Proper Orthogonal Decomposition, Experimental Thermal and Fluid Science (2018). doi $10.1016 / \mathrm{j}$. expthermflusci.2018.01.001.

[18] X. Zhang, Z. He, Q. Wang, X. Tao, Z. Zhou, X. Xia, W. Zhang, Effect of fuel temperature on cavitation flow inside vertical multi-hole nozzles and spray characteristics with different nozzle geometries, Experimental Thermal and Fluid Science (2018). doi 10.1016/j.expthermflusci.2017.06.006.

[19] D. Nguyen, D. Duke, A. Kastengren, K. Matusik, A. Swantek, C. F. Powell, D. Honnery, Spray flow structure from twin-hole diesel injector nozzles, Experimental Thermal and Fluid Science (2017). doi $10.1016 / \mathrm{j}$. expthermflusci.2017.04.020.

[20] T. Hulkkonen, T. Sarjovaara, O. Kaario, I. Hamalainen, M. Larmi, Experimental Study of Conical Diesel Nozzle Orifice Geometry, Atomization and Sprays 25 (2015) 519-538. doi 10.1615/AtomizSpr.2015010383. 
Payri, R., Hardy, G., Gimeno, J., Bautista, A. (2019). Analysis of counterbore effect in five diesel common rail injectors. Experimental Thermal and Fluid Science, 107(February), 6978. https://doi.org/10.1016/j.expthermflusci.2019.05.008

[21] F. Brusiani, S. Falfari, P. Pelloni, Influence of the diesel injector hole geometry on the flow conditions emerging from the nozzle, Energy Procedia 45 (2014) 749-758. doi $10.1016 /$ j.egypro.2014.01.080.

[22] J. Y. Koo, S. T. Hong, J. S. Shakal, S. Goto, Influence of fuel injector nozzle geometry on internal and external flow characteristics, SAE Technical Paper 970354 (1997). doi $10.4271 / 970354$.

[23] C.-w. Lee, I. Kim, K.-w. Koo, J. Park, Y. Lee, in: ICLASS 2006, Kyoto.

[24] S. Yu, B. Yin, W. Deng, H. Jia, Z. Ye, B. Xu, H. Xu, Experimental study on the spray characteristics discharging from elliptical diesel nozzle at typical diesel engine conditions, Fuel (2018). doi 10.1016/j.fuel.2018.02.090.

[25] S. Yu, B. Yin, W. Deng, H. Jia, Z. Ye, B. Xu, H. Xu, Internal flow and spray characteristics for elliptical orifice with large aspect ratio under typical diesel engine operation conditions, Fuel (2018). doi 10.1016/j.fuel.2018. 04.156

[26] R. Payri, J. P. Viera, V. Gopalakrishnan, P. G. Szymkowicz, The effect of nozzle geometry over internal flow and spray formation for three different fuels, Fuel 183 (2016) 20-33. doi:10.1016/j.fuel.2016.06.041.

[27] S. Som, A. I. Ramírez, D. E. Longman, S. K. Aggarwal, Effect of nozzle orifice geometry on spray, combustion, and emission characteristics under diesel engine conditions, Fuel 90 (2011) 1267-1276. doi 10.1016/j.fuel. 2010.10.048.

[28] L. C. Ganippa, S. Andersson, J. Chomiak, A. Matsson, Combustion characteristics of diesel sprays from equivalent nozzles with sharp and rounded inlet geometries, Combustion Science and Technology 175 (2003) 10151032. doi $10.1080 / 00102200302350$.

[29] P.-W. Tu, H. Xu, D. K. Srivastava, K. Dean, D. Jing, L. Cao, A. Weall, J. K. Venus, Numerical Investigation of GDI Injector Nozzle Geometry on Spray Characteristics, SAE 2015-01-1906 (2015). doi:10.4271/2015-01-1906. 
Payri, R., Hardy, G., Gimeno, J., Bautista, A. (2019). Analysis of counterbore effect in five diesel common rail injectors. Experimental Thermal and Fluid Science, 107(February), 6978. https://doi.org/10.1016/j.expthermflusci.2019.05.008

[30] S. Das, S.-i. Chang, J. Kirwan, Spray Pattern Recognition for Multi-Hole Gasoline Direct Injectors Using CFD Modeling, SAE Paper 2009-1488 (2009). doi $10.4271 / 2009-01-1488$.

[31] R. Payri, J. Gimeno, P. Martí-Aldaraví, D. Vaquerizo, Internal flow characterization on an ECN GDi injector, Atomization and Sprays 26 (2016) 889-919. doi 10.1615/AtomizSpr.2015013930.

[32] M. Shost, Evaluation Of Nozzle Geometry On High Pressure Gasoline Direct Injection Spray Atomization, Ph.D. thesis, Wayne State University Dissertations, 2014.

[33] K. Saha, S. Som, M. Battistoni, Y. Li, S. Quan, P. K. Senecal, Modeling of Internal and Near-nozzle Flow for a GDI Fuel Injector, Proceedings of the ASME 2015 Internal Combustion Engine Division 138 (2015) 1-13. doi $10.1115 /$ ICEF2015-1112.

[34] S. Bornschlegel, C. Conrad, A. Durst, J. Wang, M. Wensing, Multi-hole gasoline direct injection:In-nozzle flow and primary breakup investigated in transparent nozzlesand with X-ray, International Journal of Engine Research (2018). doi $10.1177 / 1468087417746860$.

[35] B. Wang, T. Badawy, P. Hutchins, P. Tu, H. Xu, X. Zhang, Numerical Investigation of the Deposit Effect on GDI Injector Nozzle Flow, Energy Procedia 105 (2017) 1671-1676. doi:10.1016/j.egypro.2017.03.545.

[36] R. Payri, J. Gimeno, P. Martí-Aldaraví, D. Vaquerizo, in: SAE Technical Paper 2015-01-1893. doi:10.4271/2015-01-1893.

[37] R. Payri, F. J. Salvador, J. Gimeno, G. Bracho, A new methodology for correcting the signal cumulative phenomenon on injection rate measurements, Experimental Techniques 32 (2008) 46-49. doi $10.1111 / \mathrm{j} .1747-1567$. 2007.00188.x.

[38] D. Vaquerizo, Study on Advanced Spray-Guided Gasoline Direct Injection Systems, Ph.D. thesis, Universitat Politècnica de València, 2017. 
Payri, R., Hardy, G., Gimeno, J., Bautista, A. (2019). Analysis of counterbore effect in five diesel common rail injectors. Experimental Thermal and Fluid Science, 107(February), 6978. https://doi.org/10.1016/j.expthermflusci.2019.05.008

[39] J. M. Desantes, R. Payri, F. J. Salvador, J. Gimeno, Measurements of spray momentum for the study of cavitation in diesel injection nozzles, SAE Technical Paper 2003-01-0703 (2003). doi 10.4271/2003-01-0703.

[40] F. Salvador, J. Lopez, J. De la Morena, M. Crialesi-Esposito, Experimental investigation of the effect of orifices inclination angle in multihole diesel injector nozzles. Part 1 Hydraulic performance, Fuel 213 (2018). doi 10. $1016 / j . f u e l .2017 .04 .019$ 